University of Wollongong

Research Online

Faculty of Informatics - Papers (Archive)

Faculty of Engineering and Information

Sciences

July 2003

\title{
The Positive Model for Offshore Team Teaching
}

Penelope McFarlane

University of Wollongong, penney@uow.edu.au

A. Fuller

University of Wollongong, annef@uow.edu.au

K. Lam

INTI College, Sarawak

Follow this and additional works at: https://ro.uow.edu.au/infopapers

Part of the Physical Sciences and Mathematics Commons

\section{Recommended Citation}

McFarlane, Penelope; Fuller, A.; and Lam, K.: The Positive Model for Offshore Team Teaching 2003. https://ro.uow.edu.au/infopapers/1 


\title{
The Positive Model for Offshore Team Teaching
}

\author{
Abstract \\ Like many western universities, the University of Wollongong is offering degrees to an increasing number \\ of offshore students. Our usual offshore teaching model involves intensive delivery of course material. \\ Disadvantages of this model include the brevity of student contact with the UOW academic and delays in \\ response to student questions and concerns regarding the subject. We discuss some results of an \\ experiment using inexpensive and readily available Internet technologies to overcome those \\ disadvantages. \\ Keywords \\ Internet, courseware, distance learning, teaching, team working \\ Disciplines \\ Physical Sciences and Mathematics \\ Publication Details \\ This article was originally published as: McFarlane, P, Fuller, A \& Lam, K, The Positive Model for Offshore \\ Team Teaching, 3rd IEEE International Conference on Advanced Learning Technologies, 9-11 July 2003, \\ 410-411. Copyright IEEE 2003.
}




\title{
The Positive Model for Offshore Team Teaching
}

\author{
Penney McFarlane \\ University of Wollongong \\ Wollongong, Australia \\ Anne Fuller \\ University of Wollongong \\ Wollongong, Australia \\ Kimberly (Cam) Lam \\ INTI College \\ Kuching, Sarawak
}

\begin{abstract}
Like many western universities, the University of Wollongong is offering degrees to an increasing number of offshore students. Our usual offshore teaching model involves intensive delivery of course material. Disadvantages of this model include the brevity of student contact with the UOW academic and delays in response to student questions and concerns regarding the subject. In this paper we discuss some results of an experiment using inexpensive and readily available Internet technologies to overcome those disadvantages.
\end{abstract}

\section{Introduction}

Early paper based approaches to distance education did not build a sense of belonging to a candidature or institution as there was little or no communication with the rest of the class. Some current methods also fail to promote collegiality between class members.

The University of Wollongong [UOW] offers degrees in partnership with Asian institutions. The usual involves an intensive one-week delivery of course material by the UOW subject coordinator. The reminder of the course is managed by local staff. We have previously identified that this approach undervalues the contribution of the local academic and inhibits the ability of the UOW academic to continue interaction with students.

This paper discusses student reactions to a trial using NetMeeting and WebCT to support offshore delivery of a computer science subject.

\section{The Experiment}

This trial was an implementation of the POSITIVE model for offshore teaching [2] (McFarlane and Fuller, 2002a). A third year computer science subject was delivered at INTI College, Kuching, Sarawak combining WebCT, telephone, email, NetMeeting, PowerPoint presentations with one week of intensive lectures. Additional lectures were subsequently presented using PowerPoint and NetMeeting for voice over commentary.

The local and Australian academic presented tutorials alternatively. The local academic's role in identifying problems by observing the students as they began working on tasks was crucial. Both academics collaborated to devise guidelines, to benefit students in accomplishing learning objectives. Email NetMeeting and the bulletin board facility of WebCT were used for this collaboration.

WebCT was found to be extremely useful in building online communities[1] (Fuller et al, 2001) and also assisted academics in determining where problems lie allowing the tailoring of supporting material.

\section{Results}

Students were surveyed in the last week of session. Of the 63 students enrolled, 57 completed the survey making it representative of the group.

Despite a commonly held notion that Asian students are reticent to participate in face-to-face discussions, 30 of the 57 respondents did not find it hard to give their opinion in a face-to-face discussion. This does not negate the use of online discussion for those students who find such conversations confronting. 43 of the students said that using online discussion forums stimulated them to think about the topics.

This experiment did not support claims that online participation can subsequently improve participation in face-to-face discussions [3] (Goldberg, Murray, 2001) (Fuller, A et al 2001). Only 26 respondents agreed that online participation helped them. 
Response to the online lectures was inconclusive. While a small majority favoured them and similarly small majority did not prefer one method of delivery to the other. It could be concluded that the combined delivery of face-to-face lectures plus online supplementary lectures is the best of both worlds, allowing students a choice between anonymity and face-to-face conversation.

\section{Conclusion}

We have successfully established that it is possible to conduct lectures using NetMeeting. Other academics at INTI are interested in this style of delivery and INTI has requested that another subject run online to extend the experiment.

INTI College believes this method of maintaining contact as valuable and has taken additional steps to further support this method of delivery. Simple technologies have been used to maintain interaction between both academic partners and offshore students.

\section{References}

[1] Fuller, Anne; Awyzio, Gene; McFarlane, Penney; (2001) "Using WebCT to support Team Teaching"; Proceedings of the IEEE International Conference of Advanced Learning Technologies

[2] Fuller, Anne; McFarlane, Penney; (2002); “An Alternate Model for Offshore Teaching" DEANZ"evolving eLearning";; Proceedings of the DEANZ Conference on eLearning

[3] Goldberg, Murray, The Asynchronous spectrum, Online Teaching and Learning Newsletter, www.otlnewsletter.com, Accessed February 2001 